\title{
Fatty acid profile of milk for determining reproductive status in lactating Holstein Friesian cows
}

\author{
by Zebari, H.M., Rutter, S.M. and Bleach, E.C.L.
}

Copyright, publisher and additional information: This is the author accepted manuscript. The final published version (version of record) is available online via Elsevier.

This version is made available under the CC-BY-ND-NC licence:

https://creativecommons.org/licenses/by-nc-nd/4.0/legalcode

Please refer to any applicable terms of use of the publisher

DOI: https://doi.org/10.1016/j.anireprosci.2019.01.004

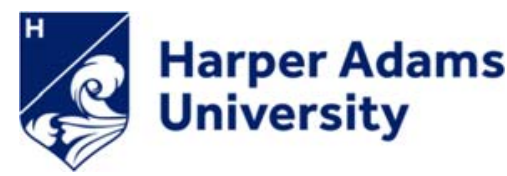

Zebari, H.M., Rutter, S.M. and Bleach, E.C.L. 2019. Fatty acid profile of milk for determining reproductive status in lactating Holstein Friesian cows. Animal Reproduction Science. 
$1 \quad$ Fatty acid profile of milk for determining reproductive status in lactating

2 Holstein Friesian cows

3 Hawar M. Zebari a,b*, S. Mark Rutter a, Emma C.L. Bleach a

4 aDepartment of Animal Production, Welfare and Veterinary Sciences, Harper Adams University,

$5 \quad$ Newport, Shropshire, TF10 8NB, UK

6 bDepartment of Animal Production, College of Agriculture, University of Duhok, Duhok, Kurdistan

7 Region, Iraq

8 *Corresponding author: Email address- hzebari@harper-adams.ac.uk (H.M. Zebari) 
Large percentages of dairy cows do not express behavioural signs of oestrus. Faecal and urine fatty acid concentrations increase during oestrus. The objective of the present study was to determine the milk FA profile of dairy cows during the oestrous and dioestrous periods and the relationship with behavioural signs on the day of oestrus. The activity of 32 Holstein Friesian cows was measured continuously using GEA Rescounter II pedometers (GEA Farm Technologies, Düsseldorf, Germany) and IceQubes (IceRobotics Ltd., Edinburgh, UK). Milk samples were collected on the day of oestrus and on day 14 of the subsequent oestrous cycle and analysed for FA concentration using gas chromatography (GC) and milk composition was also determined. All cows were artificially inseminated within $12 \mathrm{~h}$ of the onset of oestrus. On the day of oestrus, the concentration of acetic acid $(P<0.001)$, valeric acid $(P=0.016)$, caproic acid $(P<0.001)$ and myristoleic $(P=0.035)$ were greater in milk compared to day 14 . On day 14 milk arachidonic acid concentration, however, was greater $(P=0.004)$ compared to the day of oestrus. Also, on day 14 arachidonic acid concentration was greater $(P=0.002)$ in nonpregnant compared to pregnant cows. In conclusion, the results of this study indicate there are changes in the concentrations of some milk FA during oestrus and dioestrus in lactating dairy cows. 


\section{Introduction}

Oestrus is a behavioural characteristic that ensures the cow is mated close to the time of ovulation (Roelofs et al., 2010). In dairy herds using artificial insemination, detection of oestrus in a large percentage of lactating dairy cows is essential to maximise reproductive performance (Forde et al., 2011). One of the predominant reproductive dysfunctions causing poor fertility in dairy cows, however, is when there is ovulation that occurs without an associated behavioural oestrus (Yániz et al., 2008). Standing oestrous behaviour is detected in only $50 \%$ of oestrous cows (Lyimo et al., 2000). Furthermore, it has been reported (Palmer et al., 2010; Zebari et al., 2018) that only $50 \%$ to $60 \%$ of cows express behavioural signs of oestrus, with the remaining $40 \%$ to $50 \%$ having ovulations without expression of behavioural oestrus which obviously cannot be detected by observation or automated methods of oestrous detection.

Chemical communication has an important role (Sankar and Archunan, 2004) in mammalian sexual behaviour and reproductive processes. Oestrous cows produce olfactory chemical factors which attract the bull (Rekwot et al., 2001). The bull responds to pheromones (Rekwot et al., 2001), chemical factors which are released from one individual that are sensed by other individuals of the same species as a result of specific receptors for these chemicals. As a result of sensing these signals, there is induction of specific endocrine and behavioural reactions in another individual of the same species (Vyas et al., 2012). Oestrous-specific pheromones have been detected in the urine (Ramesh Kumar et al., 2000), faeces (Wiegerinck et al., 2011) and vaginal secretions (Rivard and Klemm, 1989; Rekwot et al., 2001) of cows. Bulls express the Flehmen response to vaginal secretions from oestrous cows that have been applied to cows in dioestrous (Sankar and Archunan, 2004).

In addition, oestrous and non-oestrous cows have been differentiated by bulls through the detection of pheromones in urine (Vyas et al., 2012). Various molecules have been proposed as chemical indicators of oestrus (Sankar and Archunan, 2008). During oestrus, fatty acids (FA) such as tridecanoic, myristic and pentadecanoic acids are in greater concentrations in cow urine than at other stages of the oestrous cycle (Kumar and Archunan, 2006). 
Furthermore, Gnanamuthu and Rameshkumar (2014) reported that valeric, caproic, myristic, gadoleic and pelargonic acids were present in cow faeces during oestrus but not during prooestrus and dioestrus. Mozūraitis et al. (2017) reported that the concentrations of acetic acid, propanoic acid, butanoic acid and pentanoic acid were greater in faecal samples of cows in oestrous compared with non-oestrous cows. The appearance of these FA at greater concentrations during oestrus may be due to the greater concentrations of circulating steroid hormones and may be involved in attracting the opposite sex (Kumar and Archunan, 2006).

Milk is a readily available medium with potential for oestrous detection. In a study where the day of Al was considered to be the day of oestrus, Toledo-Alvarado et al. (2018) found that specific milk fatty acid profiles changed during the oestrous phase compared to other phases of oestrous cycle. It, however, was unclear whether the cows used in this study were oestrous synchronised or naturally oestrous cycling. Although the milk from cows in oestrus attracts bulls (Sankar and Archunan, 2004), there are no known published studies relating concentrations of milk FA to oestrous activity in cows undergoing spontaneous oestrous cycles. The present study, therefore, was conducted to quantify the differences in milk FA profiles in dairy cows during oestrus and day 14 after oestrus (day 14).

\section{Material and methods}

The experiment was undertaken between August and October 2017 at the Dairy Unit of Harper Adams University, Newport, Shropshire, TF10 8NB, UK. The Harper Adams University Research Ethics Committee approved the research protocol.

\subsection{Experimental animals, housing and management}

Multiparous (parity $2.8 \pm 0.1$; range 2 to 4 ), lactating Holstein Friesian cows $(n=32)$ at 60.9 \pm 17.7 days into their lactation period were used for the study. The average locomotion score (Scale 1-5; as described by Chapinal et al., 2009) of the selected cows was $2.5 \pm 0.5$ (range 2 to 3$)$. The cows were producing $34.4 \pm 6.6 \mathrm{~kg}$ per day milk with a mean body condition score (BCS; Scale 1-5; AHDB Dairy, 2014) of $2.9 \pm 0.3$ (range 2.5 to 3.0 ) at the start of the study. Cows were housed in a free stall cubicle house (cubicles $2.7 \times 1.2 \mathrm{~m}$, with $3 \mathrm{~cm}$ thick rubber 
mattresses, 105 cubicles per 100 cows). The cubicles were bedded with sawdust three times per week and passageways were scraped using an automatic device four or five times per day. Cows were milked twice a day at approximately 05:00 and 16:30 in a 40-point internal rotary milking parlour (Westfalia, GEA Milking System, Germany).

Cows were fed a total mixed ration (TMR) ad libitum (Table 1) provided daily at approximately 07:30. Nutrients supplied in the ration are shown in Table 1. Water was also provided ad libitum from water troughs at the end of each passageway area.

\subsection{Determination of the day of oestrus and duration of oestrus}

Cows were monitored for signs of spontaneous oestrus using two automated methods throughout the duration of the experiment. These were a GEA Rescounter II pedometer (GEA Farm Technologies, Düsseldorf, Germany) attached on the right front leg and an IceQube (IceRobotics Ltd., Edinburgh, UK) attached to the back left leg of each cow.

The 'Oestrus' samples were collected on the day of behavioural oestrus. Oestrus was identified using the cows alert system (GEA Rescounter II and IceQubes). The oestrous period was identified from the increase in physical activity (GEA using an arbitrary unit; AU) and the number of steps taken (IceQube) that were $>80 \%$ of the mean number for the preceding 3 days followed by a decrease to $<80 \%$ during the following 2 days. The periods between the two basal thresholds of physical activity that were indicative of a non-oestrous animal were considered to be the period of oestrous duration (López-Gatius et al., 2008).

\subsection{Artificial insemination and pregnancy diagnosis}

All of the cows were artificially inseminated 12 hours after detection of oestrus using frozenthawed semen from one of six bulls. Cows that did not return to oestrus within 30 days of insemination ( $n=29 ; 90.6 \%$ ) were diagnosed for pregnancy status by a veterinarian using a transrectal ultrasonic device (Easi Scan-3, BCF Technology, UK). Cows were designated pregnant or non-pregnant. Cows that reinitiated oestrus 18 to 30 days after Al were also considered to be non-pregnant $(n=3 ; 9.4 \%)$. Overall, of the 32 cows, $56.3 \%(n=18)$ were diagnosed as being pregnant and $43.7 \%(n=14)$ were diagnosed as non-pregnant cows. 


\subsection{Collection of milk samples}

When oestrus was identified by both the GEA Rescounter II and IceQubes, a milk sample $(80 \mathrm{~mL})$ was collected between 1 and 12 hours after the onset of oestrus (termed the "oestrus" sample). On day 14 of the subsequent oestrous cycle, a second milk sample $(80 \mathrm{~mL})$ was collected (termed the day 14 "after oestrus" sample). The samples were aliquoted into two vessels containing $40 \mathrm{~mL}$ and stored in a freezer at $-20^{\circ} \mathrm{C}$ until analysis for short and long chain FA profiles using gas chromatography (GC - subsequently described in section 2.5 and 2.6) and milk composition using a Milko-Scan Minor analyser (Foss, Denmark) calibrated according to AOAC (2012), as described in section 2.7 .

\subsection{Short chain fatty acid determination using gas chromatography}

Short chain FA standards (acetic, propionic, iso-butyric, butyric, iso-valeric, valeric and caproic acids) as well as 2-methylvaleric acid (Sigma-Aldrich Company Ltd., Dorset, UK) were weighed $(250 \mathrm{mg})$ and placed in $50 \mathrm{~mL}$ tubes and dissolved with approximately $50 \mathrm{~mL}$ of distilled water. The volatile FA (acetic, propionic, iso-butyric, butyric, iso-valeric, valeric and caproic acids) were mixed and $0.5 \mathrm{ml}$ of this mixture was added to $0.5 \mathrm{~mL}$ of 2-methylvaleric acid solution to be used as the internal standard (Yang and Choong, 2001). This mixture (0.1 $\mu$ l) was injected into a Hewlett Packard HP6890 GC (Agilent Technologies Inc. Germany) equipped with a flame ionization detector and utilising a capillary column (30.0 m x $250 \mu \mathrm{m}$ x $0.25 \mu \mathrm{m}$ ) supplied by Greyhound Chromatography and Allied Chemicals (Merseyside, UK). The milk samples were thawed at room temperature and $1 \mathrm{~mL}$ of each sample was transferred to a GC vial and $50 \mu$ of the 2-methylvaleric acid $(0.5 \%)$ aqueous solution was added, then mixed thoroughly. There was $0.1 \mu \mathrm{l}$ of the mixture subsequently injected into the GC. The concentration of each VFA $(\mathrm{mg} / \mathrm{mL})$ was determined using the equation of Yang and Choong (2001).

\subsection{Long chain fatty determination by gas chromatography}

Milk fat for long-chain FA determination was extracted using the methods previously published by Feng et al. (2004) and a milk lipid methylation process was assessed using the methods described by Christie (1982) with modifications occurring as described by Chouinard 
et al. (1999). Long chain FA methyl esters (FAME) in hexane were prepared from milk fat by the method of Feng et al. (2004). Individual FAME was determined using a GC (HewlettPackard - HP 7820A GC System, Agilent Technologies Inc. Germany) fitted with a CP-Sil 88 column (100 m x 0.25 mm i.d. x $0.2 \mu \mathrm{m}$ film, Agilent Technologies, Santa Clara, California, USA) as described previously by Lock et al. (2006).

\subsection{Milk composition profile}

Milk samples were analysed to determine total solids, total protein, total fat, and lactose using a Milko-Scan Minor analyser (Foss, Denmark) calibrated according to AOAC (2012) for cow's milk. The samples were thawed by placement in a water bath at approximately 35 ${ }^{\circ} \mathrm{C}$ and shaking well to ensure that all of the milk contents were mixed.

\subsection{Statistics}

The milk concentrations of short chain FA, long chain FA, total fat, total protein, lactose, total solids and fat/protein ratio on the day of oestrus were compared with day 14 using a paired t-test (Genstat statistical software package, Genstat $17^{\text {th }}$ edition, 17.1.14713, VSN International Ltd, UK). Fatty acid concentrations in pregnant and non-pregnant cows were also assessed. Linear regression analysis was used to determine the relationship between GEA activity and the number of steps taken per day (from the IceQubes). Regression analyses were used to determine the relationship between the response variable, the number of steps taken per day (from the IceQubes) and the explanatory variables: acetic acid, caproic acid and valeric acid on the day of oestrus. All of the data sets analysed were normally distributed. Differences are reported as significant at $P<0.05$ and tendencies are reported when $P$ is between 0.09 and 0.05 .

\section{Results}

\subsection{Oestrous characteristics}

Spontaneous oestrous events $(n=32)$ were detected using the GEA pedometers during the study period. The average physical activity during oestrus as recorded by GEA was 768.5 \pm 37.9 AU (Mean \pm SEM; range $412-1220 \mathrm{AU}$ ). The average duration of oestrus as 
determined by the GEA pedometers was $12.8 \pm 0.6$ hours (range 7 - 19 hours). On the day of oestrus, the average number of steps recorded using the IceQube accelerometers was 2714.5 \pm 213.0 steps (range 1054 - 5381 steps). Based on the number of steps taken by cows, the average duration of oestrus was $12.6 \pm 0.6$ hours (range $7-18$ hours). There was a positive correlation $(P<0.001)$ between the GEA activity (AU/day) measurements and the number of steps recorded by the IceQube accelerometers $\left(y=0.162 x-329.84 ; r^{2}=0.821\right)$ during the day of oestrus (Fig. 1).

\subsection{Milk short chain fatty acids profile}

The concentrations of acetic acid $(\mathrm{C} 2: 0 ; P<0.001)$, valeric acid $(\mathrm{C} 5: 0 ; P=0.016)$ and caproic acid $(\mathrm{C} 6: 0 ; P<0.001)$ in milk were greater on the day of oestrus in comparison to day 14 (Table 2). Furthermore, the concentration of butyric acid $(\mathrm{C} 4: 0)$ was not significantly $(P=$ $0.131)$ greater on the day of oestrus compared to day 14 . There was no difference $(P=0.713)$ in the concentration of isovaleric acid (iso-C5:0) on the day of oestrus in comparison to day 14. Propionic acid (C3:0) was not detected in the milk samples, on either the day of oestrus or day 14 (Table 2).

There were positive quadratic relationships $(P<0.001)$, between both the milk concentrations of acetic acid $\left(y=0.03 x^{2}-9.68 x+2886.8 ; r^{2}=0.40\right.$; Fig. $\left.2 A\right)$ and caproic acid of $\left(y=6.02 x^{2}-307.68 x+5574.5 ; r^{2}=0.75 ;\right.$ Fig. $\left.2 B\right)$ and the number of steps recorded by the IceQubes during the day of oestrus. In addition, a positive linear relationship $(P=0.004)$ was observed between milk concentrations of valeric acid and the number of steps recorded by the IceQubes $\left(y=83.57 x+352.91 ; r^{2}=0.25\right.$; Fig. $\left.2 C\right)$ during the day of oestrus.

\subsection{Milk long chain fatty acids profile}

On the day 14 after oestrus, arachidonic acid (C20:4n6c) concentrations in milk samples were greater $(P=0.004)$ in comparison to the day of oestrus. Furthermore, arachidonic acid concentrations in day 14 milk samples from pregnant cows were less $(P=0.002 ; 0.53 \pm 0.02$ $\mathrm{mg} / 100 \mathrm{~mL}$; mean $\pm \mathrm{SEM})$ compared with that of non-pregnant cows $(0.64 \pm 0.02 \mathrm{mg} / 100 \mathrm{~mL})$. The concentration of undecanoic acid $(C 11: 0)$ also tended $(P=0.066)$ to be greater on day 
14 compared to the day of oestrus. In contrast, the concentration of myristoleic acid (C14:1) was greater $(P=0.035)$ on the day of oestrus, and the concentration of elaidic acid $(\mathrm{C} 18: 1 \mathrm{n} 9 \mathrm{t}$; $P>0.097)$ and lignoceric acid $(C 24: 0 ; P=0.063)$ also tended to be greater on the day of oestrus compared to day 14 . There were no significant differences in the concentrations of the other long chain FA that were assessed (Table 3) and no other differences in fatty acid concentrations of PD+ compared to PD- cows.

\subsection{Milk composition}

The concentrations of milk fat, protein, lactose and total solids were not different on the day of oestrus compared to day 14 (Table 4). There was also no effect of oestrus $(P=0.990)$ on the fat/protein ratio of milk compared to day 14 (Table 4).

\section{Discussion}

An increase in physical activity is an important external sign of oestrus in dairy cattle (Firk et al., 2003). In the present study, a concurrent increase in physical activity was recorded with use of the GEA pedometer and IceQube accelerometers. The increase in the number of steps recorded using the IceQubes was positively correlated with the concentration of acetic acid, caproic acid, valeric acid and myristoleic acid in milk on the day of oestrus. Using pedometers, Roelofs et al. (2005) there was a similar increase detected in the number of steps (2080) on the day of visually observed oestrus. In the present study, the physical activity recorded using the GEA pedometers was positively correlated $\left(y=0.162 x+329.84 ; r^{2}=0.821 ; P<0.001\right)$ with the number of steps recorded by the IceQubes on the day of oestrus. Environmental conditions including the type of housing and management conditions may affect the extent of walking activity (López-Gatius et al., 2005; Yániz et al., 2006).

Previously, the duration of standing oestrus in dairy cows was considered to be $18 \mathrm{~h}$ (Valenza et al., 2012). Oestrous duration in the present study, as recorded by the GEA pedometers and the IceQube accelerometers, was $12.8 \pm 4.6$ and $12.6 \pm 2.6 \mathrm{~h}$, respectively. Similarly, it was reported from a study conducted by Roelofs et al. (2005) using pedometers that the oestrous duration was $12.3 \mathrm{~h}$, while in a study by Silper et al. (2015), reported that 
there was a duration of oestrus of $14.3 \pm 4.1 \mathrm{~h}$ that was detected using a neck mounted accelerometer. The duration of oestrous activity in the present study, however, was shorter than that reported by Valenza et al. (2012) of $16.1 \pm 4.7 \mathrm{~h}$ detected using a physical activity monitoring system.

The findings of the present study indicated that milk concentrations of certain FA vary with the stage of the oestrous cycle. It is believed that the chemical signals from different body fluids including urine (Kumar and Archunan, 2006; Archunan, 2012), blood (Klemm et al., 1994), milk (Bendall, 2001), vaginal mucus (Sankar and Archunan, 2004) and saliva (Sankar et al., 2007) during oestrus in cattle have an important role as an attractant pheromone for bull differentiation between oestrous and non-oestrous cows. In the present study, there were greater concentrations of acetic acid (C2:0), valeric acid (C5:0) and caproic acid (C6:0) in milk on the day of oestrus compared to day 14 . As far as we are aware, this is first study where differences were reported in milk FA concentrations during different stages of spontaneous oestrous cycles. In several studies there, however, were similar differences in faecal concentrations of FA during oestrus. Mozūraitis et al. (2017) reported that there were greater concentrations of acetic acid (36 $\pm 8.0 \mathrm{ng} / 0.5 \mathrm{~g}$ faeces) and pentanoic (valeric) acid (125 \pm $57.6 \mathrm{ng} / 0.5 \mathrm{~g}$ faeces) concentrations in oestrous cows compared to those of non-oestrous cows $(19 \pm 5 \mathrm{ng} / 0.5 \mathrm{~g}$ faeces and $22.96 \pm 9.9 \mathrm{ng} / 0.5 \mathrm{~g}$ faeces, respectively). The results of the present study are also consistent with those of Sankar and Archunan (2008) in that acetic acid was present only in cow faeces during oestrus compared to pro-oestrus and post-oestrus. Furthermore, Gnanamuthu and Rameshkumar (2014) reported that valeric acid (C5:0) and caproic acid (C6:0) were present only during oestrus but in faecal samples of Bos indicus cattle collected during pro-oestrus or dioestrus. The role of these FA in relation to oestrus remains to be determined. Milk urine and vaginal secretions of volatile FA from oestrus cows, however, may have a role as a pheromone because urinary FA have a this role in mammals (Kumar and Archunan, 2006). Bendall (2001) also reported that volatile compounds in cow's milk such as the $\gamma-12: 2$ lactone functioned as an active odorant in cows. Klemm et al. (1994) found that acetaldehyde has an important function during oestrous as an attractant in cows. 
272 These findings are consistent with those from the present study and suggest the greater concentration of short-chain FA during oestrus may function as pheromones and sexual 274 attractants in cattle. Furthermore, Vyas et al. (2012) reported that cows produce a specific 275 volatile compound in markedly greater concentrations in faeces during oestrus as a sexual 276 attractant.

277 The greater concentrations of acetic acid on the day of oestrus may relate to its role as a precursor of $17 \beta$-oestradiol (Robinson et al., 2002) and milk concentrations and may simply reflect relatively greater blood acetic acid concentrations during oestrus (Frateschi et al., 1980). Results from previous studies indicate the synthesis of $17 \beta$-oestradiol by the mammary gland of cattle and the secretion into both milk and mammary venous blood (Janowski et al., 1988; Janowski et al., 2002). Without measures of milk oestradiol in the present study, however, it is not possible to explain these findings further.

Propionic acid has previously been reported to be present at high concentrations in various media. In the present study, propionic acid (C3:0), however, was not present in fresh cow's milk on either the day of oestrus or day 14 of dioestrus. This result is consistent with those reported by Bevilacqua and Califano (1989) where propionic acid was not present in the whole milk of cows but was present in yoghurt and blue cheese. From the results of the present study, there are indications that the concentration of butyric acid is greater (numerically) on the day of oestrus but not significantly different in comparison to day 14 and there were also no significant differences in the concentration of isovaleric on the day of oestrus compared to 14 after oestrus. Inconsistent with the present findings, Mozūraitis et al. (2017) reported that there was a greater concentration of butanoic (butyric) acid in faecal samples of cows in oestrus compared to those in anoestrus. This may be due to the fact that Mozūraitis et al. (2017) measured butanoic acid in the faecal samples of oestrous synchronised cows.

Dairy cow milk fat contains relatively greater amounts of long chain FA than non-fat constituents (Or-Rashid et al., 2009). In the present study, only two of the long chain FA measured differed in concentrations between samples collected during oestrus and day 14 . 
oestrus, the concentration arachidonic acid was greater in day 14 of dioestrus. In several other studies there were differences in FA concentration in both faecal and urine samples of cattle. Myristoliec acid was also found to be in greater concentrations in the milk of oestrous cows in the present study. As far as we are aware this is the first reported difference in milk myristoleic acid concentrations and the reason for these differences remains to be elucidated. Similar to the findings of the present study, in a study conducted with Holstein heifers by Lukaszewska and Hansel (1980) there were greater concentrations of arachidonic acid in plasma on the day 18 of the oestrous cycle in heifers compared with pregnant cows. The results of the present study are consistent with those of Gnanamuthu and Rameshkumar (2014) in that arachidonic acid was present in faecal samples in dioestrus but not present on the day of oestrus in cows. These findings are consistent with the finding that there are increases in plasma arachidonic acid and PGF2 $\alpha$ before luteolysis in non-pregnant cows (Mattos et al., 2003). Another interesting finding of the present study is that arachidonic acid concentrations were less in samples from pregnant compared to non-pregnant cows on day 14 of dioestrus. The mammary gland synthesizes prostaglandin (PG) F2 $\alpha$ in goats (Walker and Peaker, 1981), and arachidonic acid is a precursor of PGF2 $\alpha$. Lukaszewska and Hansel (1980) reported that the concentration of PGF2 $\alpha$ was less in the uterine vein plasma of pregnant cows compared to oestrous cyclic cows during dioestrus. This may be due to luteal tissue converting arachidonic acid to PGF2 $\alpha$ and suggests that the products of the arachidonic acid cascade, produced within or accumulated by the corpus luteum, may have an important role in the regulation of the oestrous cycle (Lukaszewska and Hansel, 1980).

In the present study, the concentration of undecanoic acid tended to be less on the day of oestrus compared to day 14 of dioestrus. The lesser concentration of undecanoic acid may be due to a negative energy balance because undecanoic acid is generally involved in amino acid metabolism and fat metabolism (Li et al., 2014). The results of the current study indicate there is a tendency for there to be greater concentrations of myristoleic, elaidic and lignoceric acids in milk on the day of oestrus compared to day 14 of dioestrus. Similarly, Kumar and Archunan (2006) also reported that the urinary concentration of tridecanoic, myristic and 
pentadecanoic acids were greater on the day of oestrus in comparison to the pre-pubertal and pregnancy periods in cattle. The results of the current study are consistent with those reported in a study conducted with Umblachery cattle by Gnanamuthu and Rameshkumar (2014) where that myristic and gadoleic acid were only present on the day of oestrus, but were not present in pro-oestrus and dioestrus. The presence of certain FA in cow's milk in greater concentrations during oestrus compared to day 14 indicates there may be a role as a chemical signal to attract bulls.

From the results of the current study, there appear to be no differences in the concentrations of the other FA measured on the day of oestrus in comparison to day 14. In a recent study conducted by Toledo-Alvarado et al. (2018), however, the concentrations of milk myristic acid $(\mathrm{C} 14: 0)$ and palmitic acid $(\mathrm{C} 16: 0)$ were less on the day of oestrus compared to dioestrus. In addition, it was reported that the concentrations of stearic acid (C18:0) and oleic acid (C18:1 cis-9) were greater on the day of oestrus compared to other phases of oestrous cycle. This may reflect the large number of samples analysed in their study. Similar to the findings of the present study, Gnanamuthu and Rameshkumar (2014) reported that there were no differences in the concentration of faecal stearic acid in oestrus and dioestrus cows. Also, Gnanamuthu and Rameshkumar (2014) reported the concentration of palmitic, elaidic and behenic acids in cattle faeces did not differ between pro-oestrus and dioestrus. In another study conducted in cattle (Bos taurus), Kumar and Archunan (2006) analysed FA in urine, and reported that lauric, tridecanoic, myristic and stearic were present in pro-oestrus, oestrus and dioestrus samples but were not different in concentration. Although Megalac is a source of C16:0 and C18:1n9c FA (Scollan et al., 2001), and dry matter intake has been previously shown to be reduced during oestrus (Zebari et al., 2018) C16:0 and C18:1n9c FA concentrations were similar during oestrus and day 14 of dioestrus in the present study.

From the results of the current study, total milk fat, protein, lactose and solids, as well as the fat/protein ratio, were not different on the day of oestrus in comparison to day 14 of dioestrus. Gnanamuthu and Rameshkumar (2014), however, reported that the total concentration of protein, carbohydrate and lipid in faecal samples on the day of oestrus were 
greater in comparison to the pro-oestrous and the post-oestrous phase of the oestrous cycle

357 in cows. Although in the results of the present study there were no significant differences in 358 the composition of milk between oestrus and day 14 of dioestrus, it has previously been 359 reported that lipids (Poddar-Sarkar and Brahmachary, 1999; Kumar and Archunan, 2006) and 360 proteins (Zhou and Rui, 2010) in mammalian urine and faeces have an important role as a carrier of olfactory chemical signals in sexual attraction. Proteins and lipids, therefore, may also have an important role as carriers for the ligands and for transportation of these chemical signals in mammals, while the role of milk carbohydrates in sexual attraction is unknown 364 (Gnanamuthu and Rameshkumar, 2014).

\section{Conclusion}

As far as we are aware, this is the first study in which there was changes in the concentrations of some milk FA during behavioural oestrus in dairy cows undergoing spontaneous oestrous cycles. Further research is needed to establish the potential for using milk FA profiles as part of our on-farm oestrous detection procedures.

\section{Conflict of interest}

None.

\section{Acknowledgements}

The study was financially supported by HCED-Iraq. Special thanks to the HAU farm staff for their assistance. 


\section{References}

AHDB 2014. Body condition scoring. [Online] Accessed online at 07-03-2014. (https://dairy.ahdb.org.uk/resources-library/technical-information/healthwelfare/body-condition-scoring/\#.Wqach-jFKUk).

AOAC, 2012. Official methods of Analysis. 19th edn. Association of Official Analyrical Chemists, Arlington, VA.

Archunan, G., 2012. 1-lodoundecane, an Estrus Indicating Urinary Chemo signal in Bovine(Bos Taurus). J. Vet. Sci. Technol. 03, 3-5. https://doi.org/10.4172/21577579.1000121

Bendall, J.G., 2001. Aroma compounds of fresh milk from New Zealand cows fed different diets. J. Agric. Food Chem. 49, 4825-4832. https://doi.org/10.1021/jf010334n

Bevilacqua, a. E., Califano, a. N., 1989. Determination of Organic Acids in Dairy Products by High Performance Liquid Chromatography. J. Food Sci. 54, 1076-1076. https://doi.org/10.1111/j.1365-2621.1989.tb07948.x

Chapinal, N., de Passillé, A.M., Weary, D.M., von Keyserlingk, M.A.G., Rushen, J., 2009. Using gait score, walking speed, and lying behavior to detect hoof lesions in dairy cows. J. Dairy Sci. 92, 4365-4374. https://doi.org/10.3168/jds.2009-2115

Chouinard, P.Y., Corneau, L., Sæbø, A., Bauman, D.E., 1999. Milk Yield and Composition During Abomasal Infusion of Conjugated Linoleic Acids in Dairy Cows1. J. Dairy Sci. $82,2737-2745$.

Christie, W.W., 1982. A simple procedure for rapid transmethylation of glycerolipids and cholesteryl esters. J. Lipid Res. 23, 1072-1075.

Feng, S., Lock, A.L., Garnsworthy, P.C., 2004. A rapid lipid separation method for determining fatty acid composition of milk. J. Dairy Sci. 87, 3785-3788. 
Firk, R., Stamer, E., Junge, W., Krieter, J., 2003. Improving oestrus detection by combination of activity measurements with information about previous oestrus cases. Livest. Prod. Sci. 82, 97-103. https://doi.org/10.1016/S0301-6226(02)00306-8

Forde, N., Beltman, M.E., Lonergan, P., Diskin, M., Roche, J.F., Crowe, M.A., 2011. Oestrous cycles in Bos taurus cattle. Anim. Reprod. Sci. 124, 163-169. https://doi.org/10.1016/j.anireprosci.2010.08.025

Frateschi, T.L., Mariani, A.P., Martelli, F., Sighieri, C., Preziuso, F., Colombani, B., 1980. [Blood and milk fatty acids in dairy cattle at various seasons].[Italian]. Ann. della Fac. di Med. Vet. di Pisa.

Gnanamuthu, G., Rameshkumar, K., 2014. Biochemical and fatty acid analysis of faeces in Umblachery cattle (Bos Indicus) during different phases of estrous cycle. Res J An Vet Fish Sci. 2, 1-5.

Janowski, T., Czyk, S.Z., Ras, A., Okrasa, S., 1988. Prostaglandin F2a in C o w s near P a r t u rition $17,297-302$.

Janowski, T., Zduńczyk, S., Małecki-Tepicht, J., Barański, W., Raś, A., 2002. Mammary secretion of oestrogens in the cow. Domest. Anim. Endocrinol. 23, 125-137. https://doi.org/10.1016/S0739-7240(02)00151-0

Klemm, W.R., Rivard, G.F., Clement, B.A., 1994. Blood acetaldehyde fluctuates markedly during bovine estrous cycle. Anim. Reprod. Sci. 35, 9-26.

Kumar, K.R., Archunan, G., 2006. Analysis of urinary fatty acids in bovine (Bos taurus): An effective method for estrus detection. Indian J. Anim. Sci. 76.

Li, Y., Xu, C., Xia, C., Zhang, H., Sun, L., Gao, Y., 2014. Plasma metabolic profiling of dairy cows affected with clinical ketosis using LC/MS technology. Vet. Q. 34, 152-158. https://doi.org/10.1080/01652176.2014.962116 
López-Gatius, F., López-Béjar, M., Fenech, M., Hunter, R.H.F., 2005. Ovulation failure and double ovulation in dairy cattle: Risk factors and effects. Theriogenology 63,1298 1307. https://doi.org/10.1016/j.theriogenology.2004.06.010

López-Gatius, F., Mirzaei, A., Santolaria, P., Bech-Sàbat, G., Nogareda, C., García-Ispierto, I., Hanzen, C., Yániz, J.L., 2008. Factors affecting the response to the specific treatment of several forms of clinical anestrus in high producing dairy cows. Theriogenology 69, 1095-1103. https://doi.org/10.1016/j.theriogenology.2008.01.023

Lukaszewska, J., Hansel, W., 1980. Corpus luteum maintenance during early pregnancy in the cow. J. Reprod. Fertil. 59, 485-93. https://doi.org/10.1530/jrf.0.0590485

Lyimo, Z.C., Nielen, M., Ouweltjes, W., Kruip, T.A.M., Van Eerdenburg, F.J.C.M., 2000. Relationship among estradiol, cortisol and intensity of estrous behavior in dairy cattle. Theriogenology 53, 1783-1795. https://doi.org/10.1016/S0093-691X(00)00314-9

Mattos, R., Guzeloglu, A., Badinga, L., Staples, C.R., Thatcher, W.W., 2003. Polyunsaturated Fatty Acids and Bovine Interferon-т Modify Phorbol Ester-Induced Secretion of Prostaglandin F2 $\alpha$ and Expression of Prostaglandin Endoperoxide Synthase-2 and Phospholipase-A2 in Bovine Endometrial Cells1. Biol. Reprod. 69, 780-787. https://doi.org/10.1095/biolreprod.102.015057

Mozūraitis, R., Kutra, J., Borg-Karlson, A.-K., Būda, V., 2017. Dynamics of putative sex pheromone components during heat periods in estrus-induced cows. J. Dairy Sci. 100, 7686-7695. https://doi.org/10.3168/jds.2016-12376

Or-Rashid, M.M., Odongo, N.E., Wright, T.C., McBride, B.W., 2009. Fatty acid profile of bovine milk naturally enhanced with docosahexaenoic acid. J. Agric. Food Chem. 57, 1366-1371. https://doi.org/10.1021/jf802989p

Palmer, M.A., Olmos, G., Boyle, L.A., Mee, J.F., 2010. Estrus detection and estrus characteristics in housed and pastured Holstein-Friesian cows. Theriogenology 74 , 
Poddar-Sarkar, M., Brahmachary, R.L., 1999. Can free fatty acids in the tiger pheromone act as an individual finger print? Curr. Sci. $76,141-142$.

Ramesh Kumar, K., Archunan, G., Jeyaraman, R., Narasimhan, S., 2000. Chemical characterization of bovine urine with special reference to oestrus. Vet. Res. Commun. 24, 445-454. https://doi.org/10.1023/A:1006495404407

Rekwot, P.I., Ogwu, D., Oyedipe, E.O., Sekoni, V.O., 2001. The role of pheromones and biostimulation in animal reproduction. Anim. Reprod. Sci. 65, 157-170. https://doi.org/10.1016/S0378-4320(00)00223-2

Rivard, G., Klemm, W.R., 1989. Two body fluids containing bovine estrous pheromone(s). Chem. Senses 14, 273-279. https://doi.org/10.1093/chemse/14.2.273

Robinson, R., Pushpakumara, P., Cheng, Z., Peters, A., Abayasekara, D., Wathes, D., 2002. Effects of dietary polyunsaturated fatty acids on ovarian and uterine function in lactating dairy cows. Reproduction 124, 119-131. https://doi.org/10.1530/rep.0.1240119

Roelofs, J., López-Gatius, F., Hunter, R.H.F., van Eerdenburg, F.J.C.M., Hanzen, C., 2010. When is a cow in estrus? Clinical and practical aspects. Theriogenology $74,327-344$. https://doi.org/10.1016/j.theriogenology.2010.02.016

Roelofs, J.B., Van Eerdenburg, F.J.C.M., Soede, N.M., Kemp, B., 2005. Pedometer readings for estrous detection and as predictor for time of ovulation in dairy cattle. Theriogenology 64, 1690-1703. https://doi.org/10.1016/j.theriogenology.2005.04.004

Sankar, R., Archunan, G., 2008. Identification of putative pheromones in bovine (Bos taurus) faeces in relation to estrus detection. Anim. Reprod. Sci. 103, 149-153. https://doi.org/10.1016/j.anireprosci.2007.04.014

Sankar, R., Archunan, G., 2004. Flehmen response in bull: Role of vaginal mucus and other 
body fluids of bovine with special reference to estrus. Behav. Processes 67, 81-86. https://doi.org/10.1016/j.beproc.2004.02.007

Sankar, R., Archunan, G., Habara, Y., 2007. Detection of oestrous-related odour in bovine (Bos taurus) saliva: Bioassay of identified compounds. Animal 1, 1321-1327. https://doi.org/10.1017/S1751731107000614

Scollan, N.D., Dhanoa, M.S., Choi, N.J., Maeng, W.J., Enser, M., Wood, J.D., 2001. Biohydrogenation and digestion of long chain fatty acids in steers fed on different sources of lipid. J. Agric. Sci. 136, 345-355.

Silper, B.F., Madureira, A.M.L., Kaur, M., Burnett, T.A., Cerri, R.L.A., 2015. Short communication: Comparison of estrus characteristics in Holstein heifers by 2 activity monitoring systems. J. Dairy Sci. 98, 3158-3165. https://doi.org/10.3168/jds.2014-9185

Toledo-Alvarado, H., Vazquez, A.I., de los Campos, G., Tempelman, R.J., Gabai, G., Cecchinato, A., Bittante, G., 2018. Changes in milk characteristics and fatty acid profile during the estrous cycle in dairy cows. J. Dairy Sci. 101, 9135-9153.

Valenza, A., Giordano, J.O., Lopes, G., Vincenti, L., Amundson, M.C., Fricke, P.M., 2012. Assessment of an accelerometer system for detection of estrus and treatment with gonadotropin-releasing hormone at the time of insemination in lactating dairy cows. J. Dairy Sci. 95, 7115-7127. https://doi.org/10.3168/jds.2012-5639

Vyas, S., Briant, C., Chemineau, P., Le Danvic, C., Nagnan-Le Meillour, P., 2012. Oestrus pheromones in farm mammals, with special reference to cow. Indian J. Anim. Sci. 82, 256-267.

Walker, F.M.M., Peaker, M., 1981. From the ARC. Institute of Animal Physiology, Babraham, Cambridge CB2 4AT, UK, and the Hannah Research Institute, Ayr, Scotland KA6 SHL. Acta wet. scand 77, 299-310. 
Wiegerinck, W., Setkus, A., Buda, V., Borg-Karlson, A.K., Mozuraitis, R., De Gee, A., 2011. BOVINOSE: Pheromone-based sensor system for detecting estrus in dairy cows. Procedia Comput. Sci. 7, 340-342. https://doi.org/10.1016/j.procs.2011.09.024

Yang, M.-H., Choong, Y.-M., 2001. A rapid gas chromatographic method for direct determination of short-chain (C2-C12) volatile organic acids in foods. Food Chem. 75 , 101-108. https://doi.org/10.1016/S0308-8146(01)00211-4

Yániz, J., López-Gatius, F., Bech-Sàbat, G., García-Ispierto, I., Serrano, B., Santolaria, P., 2008. Relationships between milk production, ovarian function and fertility in highproducing dairy herds in north-eastern Spain. Reprod. Domest. Anim. 43, 38-43. https://doi.org/10.1111/j.1439-0531.2008.01227.x

Yániz, J.L., Santolaria, P., Giribet, A., López-Gatius, F., 2006. Factors affecting walking activity at estrus during postpartum period and subsequent fertility in dairy cows. Theriogenology 66, 1943-1950. https://doi.org/10.1016/j.theriogenology.2006.05.013

Zebari, H.M., Rutter, S.M., Bleach, E.C.L., 2018. Characterizing changes in activity and feeding behaviour of lactating dairy cows during behavioural and silent oestrus. Appl. Anim. Behav. Sci. 206C, 12-17. https://doi.org/10.1016/J.APPLANIM.2018.06.002

Zhou, Y., Rui, L., 2010. Major urinary protein regulation of chemical communication and nutrient metabolism, 1st ed, Vitamins and Hormones. Elsevier Inc. https://doi.org/10.1016/S0083-6729(10)83006-7. 


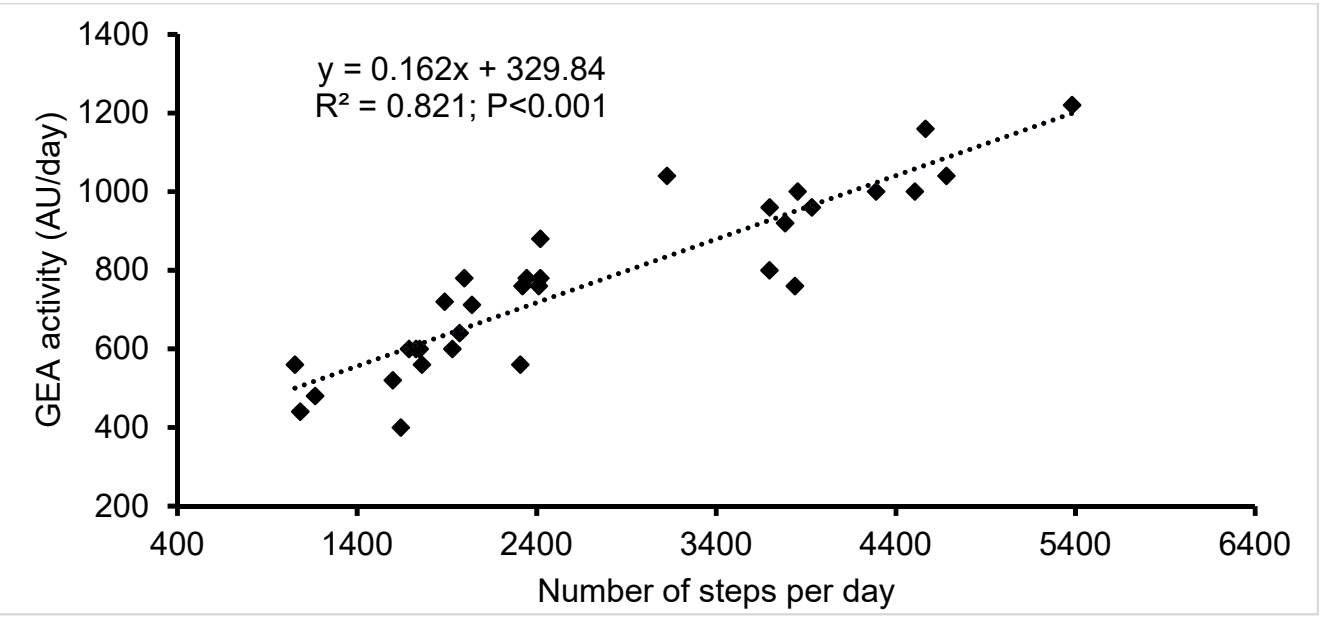

527 Fig. 1. Relationship between GEA activity (AU per day) recorded by the GAE pedometers and 528 the number of steps per day recorded by the IceQube accelerometers on the day of oestrus in Holstein Friesian cows $(n=32)$. 
Table 1.

543 Ingredients (kgDM/animal/day) and nutrient supply ( $/ \mathrm{kg} \mathrm{DM}$ ) of the total mixed ration fed to

544 dairy cows throughout the study

\begin{tabular}{|c|c|c|}
\hline Ingredients & Kg DM/animal & 545 \\
\hline Maize silage & 8.84 & 546 \\
\hline Grass silage & 1.56 & 547 \\
\hline Lucerne & 3.15 & \\
\hline Chopped wheat straw & 0.30 & 548 \\
\hline Protein syrup & 0.96 & 549 \\
\hline Protein blend & 4.66 & 550 \\
\hline Sweet starch & 1.98 & 551 \\
\hline Soya hulls & 1.80 & 552 \\
\hline Megalac & 0.20 & 553 \\
\hline Dairy minerals & 0.15 & 554 \\
\hline Acid buff & 0.10 & \\
\hline Salt & 0.09 & 555 \\
\hline Saccharomyces cerevisiae & 0.02 & 556 \\
\hline Water & 0.0 & 557 \\
\hline Total & 22.47 & 558 \\
\hline Nutrient supply & $\mathrm{g} / \mathrm{kg} \mathrm{DM}$ & 559 \\
\hline $\mathrm{DM}$ (g/kg fresh) & 430.0 & 560 \\
\hline ME (MJ/kgDM) & 12.1 & \\
\hline Crude protein (\%DM) & 16.7 & 561 \\
\hline NDF (\%DM) & 36.1 & 562 \\
\hline Ether extract (\%DM) & 4.4 & 563 \\
\hline Starch and sugar (\%DM) & 20.9 & 564 \\
\hline
\end{tabular}

565 (Profeed Nutrition Consultancy, UK, 2017) 
Table 2

568 Milk short chain FA (mg/100 mL) concentrations (means \pm SEM) on the day of oestrus and 569 day 14 of dioestrus in lactating Holstein Friesian dairy cows $(n=32)$

\begin{tabular}{lllll}
\hline $\begin{array}{l}\text { Short chain } \\
\text { FA }\end{array}$ & Lipid number & $\begin{array}{l}\text { Oestrus } \\
(\mathrm{mg} / 100 \mathrm{~mL})\end{array}$ & $\begin{array}{l}\text { Day 14 } \\
(\mathrm{mg} / 100 \mathrm{~mL})\end{array}$ & P-value \\
\hline Acetic acid & C2:0 & $297.0 \pm 18.5$ & $229.0 \pm 11.9$ & 0.001 \\
Propoinic acid & C3:0 & N/A & N/A & N/A \\
Butyric acid & C4:0 & $179.1 \pm 6.8$ & $157.3 \pm 11.4$ & 0.131 \\
IsoValeric acid & Iso C5:0 & $389.0 \pm 18.7$ & $380.0 \pm 18.1$ & 0.713 \\
Valeric acid & C5:0 & $28.3 \pm 1.3$ & $23.7 \pm 1.0$ & 0.016 \\
Caproic acid & C6:0 & $35.3 \pm 1.7$ & $28.7 \pm 1.1$ & 0.001 \\
\hline
\end{tabular}

570

571

572

573

574

575

576

577

578

579

580

581 


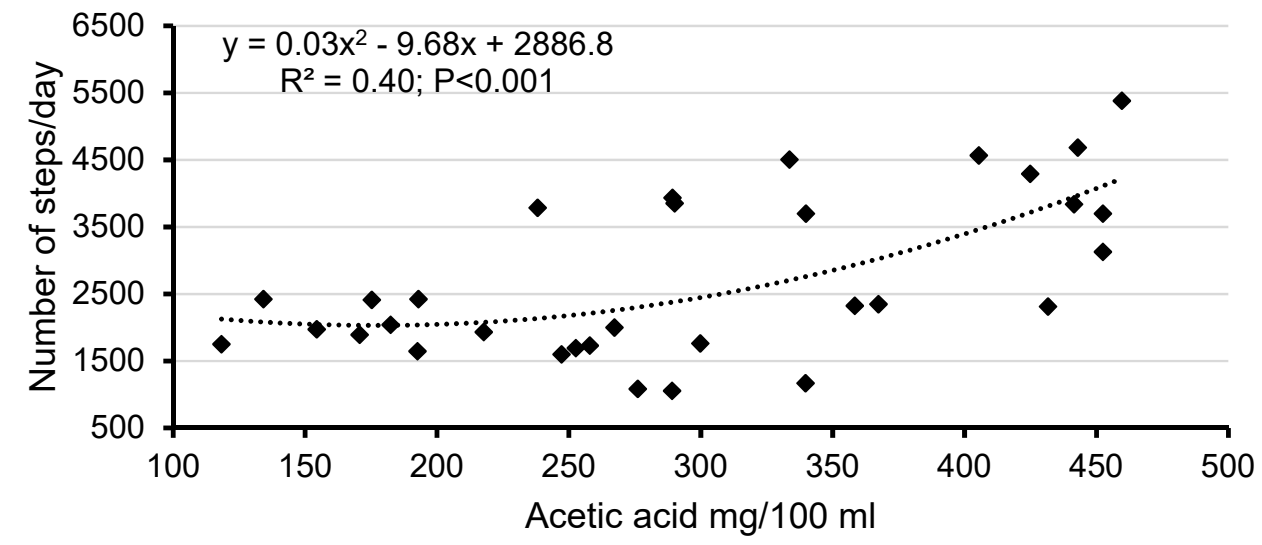

$584 \quad$ (B)

585

586

587

588

589

B)

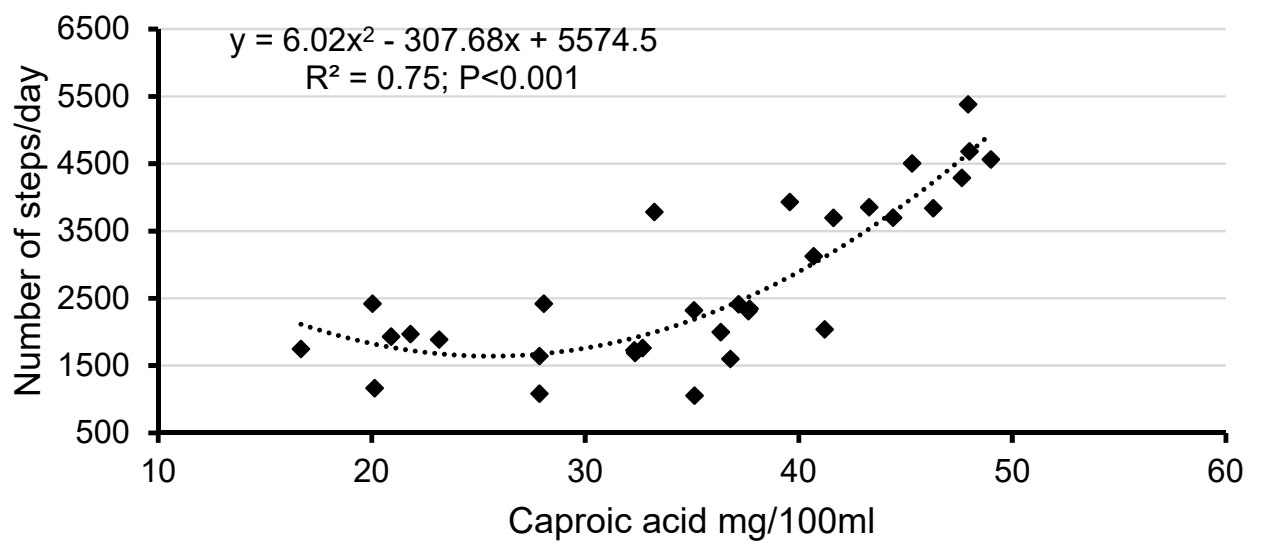

(C)

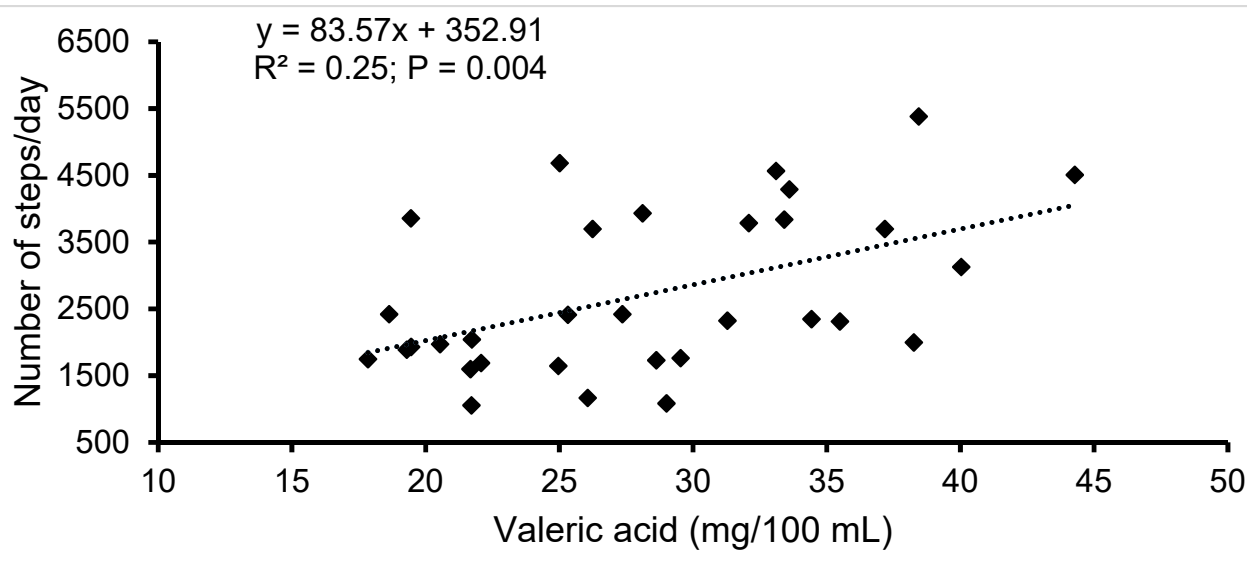

Fig. 2. Association between acetic acid (A), caproic acids (B) and valeric acids (C) concentrations (mg per $100 \mathrm{~mL}$ ) in milk and the number of steps recorded by lceQube accelerometers on the day of oestrus in Holstein Friesian cows $(n=32)$ 
Table 3

592 Milk long chain FA ( $\mathrm{g} / 100 \mathrm{~g}$ of FA) concentrations (mean \pm SEM) on the day of oestrus and

day 14 after oestrus of lactating Holstein Friesian dairy cows $(n=32)$

\begin{tabular}{|c|c|c|c|c|}
\hline Long chain FA & $\begin{array}{l}\text { Lipid } \\
\text { number }\end{array}$ & Oestrus & Day 14 & $P$-value \\
\hline Caprylic acid & $\mathrm{C} 8: 0$ & $1.13 \pm 0.02$ & $1.13 \pm 0.03$ & 0.965 \\
\hline Capric acid & C10:0 & $2.70 \pm 0.06$ & $2.62 \pm 0.07$ & 0.353 \\
\hline Undecanoic acid & C11:0 & $0.23 \pm 0.01$ & $0.25 \pm 0.01$ & 0.066 \\
\hline Lauric acid & $\mathrm{C} 12: 0$ & $3.44 \pm 0.08$ & $3.38 \pm 0.09$ & 0.470 \\
\hline Tridecanoic acid & C13:0 & $0.11 \pm 0.01$ & $0.09 \pm 0.00$ & 0.171 \\
\hline Myristic acid & $\mathrm{C} 14: 0$ & $10.28 \pm 0.21$ & $10.50 \pm 0.18$ & 0.289 \\
\hline Myristoleic acid & $\mathrm{C} 14: 1$ & $0.62 \pm 0.12$ & $0.32 \pm 0.03$ & 0.035 \\
\hline Palmitic acid & $\mathrm{C} 16: 0$ & $29.16 \pm 0.50$ & $29.12 \pm 0.50$ & 0.928 \\
\hline Palmitoleic acid & $\mathrm{C} 16: 1$ & $1.34 \pm 0.07$ & $1.39 \pm 0.06$ & 0.361 \\
\hline Heptadecanoic acid & $\mathrm{C} 17: 0$ & $0.13 \pm 0.01$ & $0.16 \pm 0.03$ & 0.335 \\
\hline Cis-10- Heptadecenoic acid & $\mathrm{C} 17: 1$ & $0.53 \pm 0.01$ & $0.51 \pm 0.01$ & 0.164 \\
\hline Stearic acid & C18:0 & $10.01 \pm 0.38$ & $9.85 \pm 0.33$ & 0.743 \\
\hline Oleic acid & $\mathrm{C} 18: 1 \mathrm{n} 9 \mathrm{c}$ & $22.08 \pm 0.55$ & $21.33 \pm 0.60$ & 0.230 \\
\hline Linoliec acid & $\mathrm{C} 18 \mathrm{an} 6 \mathrm{c}$ & $2.65 \pm 0.10$ & $2.65 \pm 0.09$ & 0.998 \\
\hline Elaidic acid & $\mathrm{C} 18: 1 \mathrm{n} 9 \mathrm{t}$ & $0.95 \pm 0.15$ & $0.65 \pm 0.08$ & 0.097 \\
\hline Arachidic acid & C20:0 & $0.13 \pm 0.01$ & $0.14 \pm 0.01$ & 0.308 \\
\hline Gadoliec acid & $\mathrm{C} 20: 1 \mathrm{n} 9 \mathrm{t}$ & $0.39 \pm 0.03$ & $0.42 \pm 0.01$ & 0.250 \\
\hline Arachidonic acid & $\mathrm{C} 20: 4 \mathrm{n} 6 \mathrm{c}$ & $0.41 \pm 0.05$ & $0.60 \pm 0.03$ & 0.004 \\
\hline Henicosanoic acid & $\mathrm{C} 21: 0$ & $0.17 \pm 0.06$ & $0.10 \pm 0.01$ & 0.102 \\
\hline Behenic acid & $\mathrm{C} 22: 0$ & $0.15 \pm 0.01$ & $0.16 \pm 0.01$ & 0.655 \\
\hline Tricosanoic acid & C23:0 & $0.06 \pm 0.01$ & $0.07 \pm 0.01$ & 0.509 \\
\hline Lignoceric acid & $\mathrm{C} 24: 0$ & $0.09 \pm 0.01$ & $0.07 \pm 0.01$ & 0.063 \\
\hline
\end{tabular}

594

595

596

597

598

599

600 
Table 4

602 Milk compositions and fat/protein ratio (mean \pm SEM; $\mathrm{g} / \mathrm{kg}$ ) on the day of oestrus and day 14 603 after oestrus in lactating Holstein Friesian dairy cows $(n=32)$

\begin{tabular}{llll}
\hline Milk composition & Oestrus & Day 14 & $P$-value \\
\hline Fat & $35.2 \pm 1.4$ & $36.8 \pm 1.4$ & 0.465 \\
Protein & $32.1 \pm 0.6$ & $33.7 \pm 1.2$ & 0.171 \\
Lactose & $45.5 \pm 0.7$ & $46.1 \pm 0.6$ & 0.427 \\
Total solid & $147 \pm 2.1$ & $150.5 \pm 2.3$ & 0.390 \\
Fat/Protein & $1.1 \pm 0.0$ & $1.1 \pm 0.0$ & 0.990 \\
\hline
\end{tabular}

604

605

606 